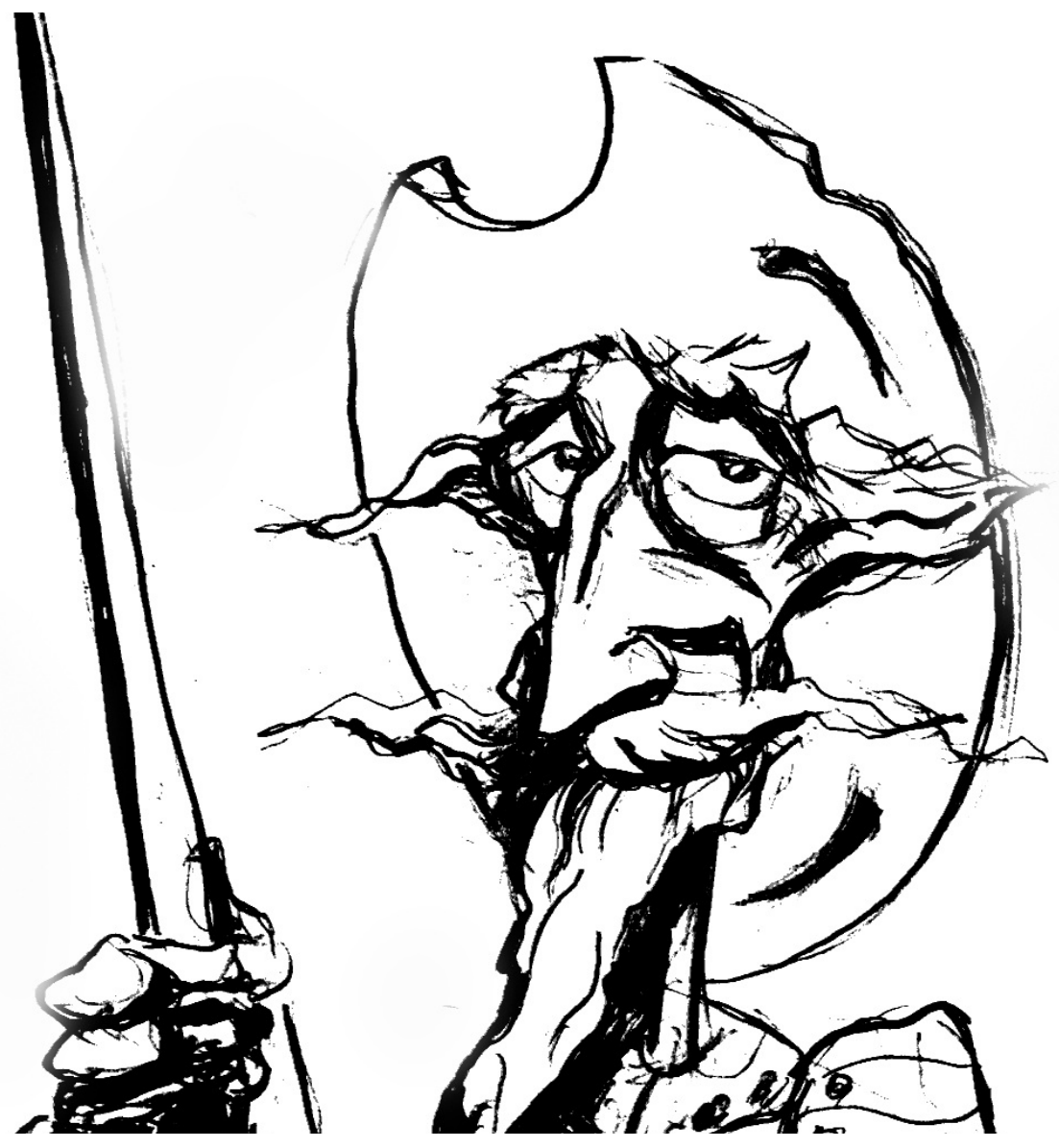

En torno a El enigma Belgrano de Tulio Halperin Donghi y los contextos de construcción del héroe

[Alejandro Eujanian] 



\section{En torno a El enigma Belgrano de Tulio Halperin Donghi y los contextos de construcción del héroe*}

\section{On the Subject of El Enigma Belgrano by Tulio Halperin Donghi and the Contexts of the Hero's Construction}

ALEJANDRO EUJANIAN

\begin{abstract}
Resumen
Parto del problema del héroe planteado por Tulio Halperin Donghi en El enigma Belgrano, para reformularlo y responderlo no por medio de su biografía sino del proceso de construcción de su figura ejemplar. Analizo los rituales fúnebres, primer momento de plasmación de modos de representación del héroe. A continuación, examino la poesía patriótica a través de la cual esas representaciones fueron trasmitidas entre generaciones. Finalmente, reconstruyo el proceso a través del cual la biografía de Belgrano se integró en una narrativa nacional que se consolidó con la inauguración de su monumento en 1873, cuando se privilegió su asociación casi exclusiva a la creación de la bandera nacional.
\end{abstract}

\section{Palabras clave}

Manuel Belgrano; Héroe; Tulio Halperin Donghi; Rituales fúnebres; Representaciones

\begin{abstract}
In this paper we will deal with the issue of the hero raised by Tulio Halperín Donghi in El Enigma Belgrano, to reformulate and answer it, not through Belgrano's biography, but through the process that led to the creation of his exemplary figure. We will analyze the funerary rites, the initial instance where the different ways of representation of the hero were materialized. We will then examine the patriotic poetry that allowed for those representations to be transmitted from generation to generation. Finally, we will reconstruct the process through which Belgrano's biography became part of a national narrative that was consolidated with the inauguration of his monument in 1873 when his figure will be linked almost exclusively to the creation of the national flag.
\end{abstract}

Keywords

Manuel Belgrano; Hero; Tulio Halperin Donghi; Funerary rites; Representation

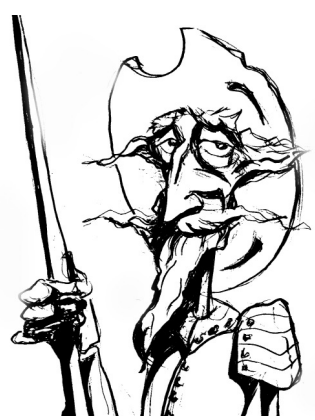

Recibido con pedido de publicación el 20 de abril de 2020

Aceptado para su publicación el 25 de junio de 2020

Versión definitiva recibida el 31 de julio de 2020

Alejandro Eujanian, Instituto de Estudios Críticos en Humanidades (IECH), Universidad Nacional de Rosario (UNR), Rosario, Argentina; e-mail: alejandroeujanian@fhumyar.unr.edu.ar

\footnotetext{
* Agradezco los comentarios de los evaluadores anónimos de la revista; y, asimismo, a Morena Eujanian por la traducción del resumen al inglés.
}

Esta obra se publica bajo licencia Creative Commons. Atribución-NoComercial-CompartirIgual $($ (c) EY-NC-SA 4.0 Internacional

Eujanian, Alejandro "En torno a El enigma Belgrano de Tulio Halperin Donghi y los contextos de construcción del héroe", Prohistoria, Año XXIII, núm. 34, dic. 2020, pp. 281-313. 


\title{
Introducción
}

\author{
"No eres, Muerte, quien \\ por nombre de misterio \\ pueda a mi mente hacer pálida \\ cual a los cuerpos haces" \\ Macedonio Fernández ${ }^{1}$
}

En noviembre de 2014, casi al mismo tiempo que se publicaba su último libro, El enigma Belgrano. Un héroe para nuestro tiempo, falleció Tulio Halperin Donghi, quien para muchos fue el más relevante e inimitable historiador de la Argentina del siglo XX (Halperin Donghi, 2014). Inmediatamente la comunidad de historiadores realizó una multitud de homenajes que promovieron una amplia revisión de su obra con el fin de valorar sus aportes a la historia política, social, económica y de las ideas del siglo XIX y XX. En aquella ocasión no me decidí a escribir sobre ese libro, sobre todo porque me parecía que el problema que a mi entender planteaba debía ser analizado a través de un estudio que excedía las reglas de juego de una crítica bibliográfica (Eujanian y Ternavasio, 2016; Eujanian, 2017: 75-85). Finalmente, el doble aniversario de Belgrano en el 2020 y la cuarentena obligada por la pandemia que azotó al mundo este año me dieron la oportunidad para retomar ese proyecto.

La reflexión comienza con un enigma. Por qué al final de su prestigiosa trayectoria de historiador poco dispuesto a caer en lugares comunes decidió dedicar un breve ensayo a un personaje que, según confiesa, le había resultado lo suficientemente esquivo como para excluirlo del grupo de letrados que seleccionó para explorar las diversas trayectorias que habían trazado tras la crisis del Antiguo Régimen colonial (Halperin Donghi, 2013). Por otra parte, la convicción, sin duda irónica, de que se trata de "un héroe para nuestro tiempo" solo se justifica al final de su vida en la lamentable comprobación de que Argentina era un país que le resultaba incomprensible. Aun así, no deja de sorprender esa última empresa en quien no había explorado hasta ese momento la búsqueda del hombre ejemplar, para ningún tiempo y lugar, sobre todo porque sus personajes preferidos se caracterizaban por la dificultad que tenían para interpretar circunstancias que en general les resultaban indescifrables. Por qué sería un enigma la condición de héroe de quien a lo largo de su vida cosechó menos éxitos que fracasos, cuando esa falta de fortuna y de fallas no se encuentra ausente en los héroes clásicos (Campbell, 1972: 198). Ignorancia, sufrimiento y realización de su destino son esenciales en la construcción del

\footnotetext{
${ }^{1}$ Macedonio Fernández, "Elena Bellamuerte"; los versos son insertados en el poema de Oliva, Aldo (2003). "Anábasis hacia el turbio Sur", Ese general Belgrano y otros poemas. Poesía Completa, Rosario: Editorial Municipal de Rosario, pp. 307 y 308.
} 
mito del héroe trágico, es decir, de su posteridad. En cualquier caso, por qué la respuesta al enigma así formulado la encontraríamos en "el mismo Belgrano", antes que en el proceso durante el cual se construyó su imagen pública de héroe máximo del panteón nacional, a lo largo de los cincuenta años posteriores a su muerte.

En este texto, parto del problema histórico en torno al héroe planteado por Tulio Halperin Donghi, para luego optar por otro modo de formular el enigma y, a partir de allí, transitar otros senderos para responderlo. Para ello consideramos necesario reponer los contextos en los que Manuel Belgrano se instaló cómodamente en un sitial de honor del panteón nacional. A lo largo de esos años, si hubo un enigma que afectaba a Belgrano, no fue otro que el que planteaba la Revolución de Mayo en sí misma: cuáles fueron sus causas, sus objetivos, su significado, sus héroes.

Por otro lado, sobre todo a partir de la década de 1850, que fue cuando tanto Manuel Belgrano como José de San Martín fueron elevados a ese lugar de privilegio, el principal enigma es por qué los dos héroes más relevantes de ese panteón carecían de los atributos que requería en ese momento la república liberal que se estaba fundando sobre nuevos cimientos. En efecto, tanto San Martín como Belgrano impulsaron en el mismo momento en el que se declaraba la independencia proyectos monárquicos, no manifestaron intensiones democratizantes ni tampoco posiciones favorables al federalismo en un momento en el que los pueblos se encontraban en franco proceso de convertirse en provincias. Por todos esos motivos Belgrano fue cuestionado y en ese sentido fue menos excepcional de lo que Tulio Halperin Donghi sostiene.

Para responder a estas preguntas, menos que la vida de Belgrano son las circunstancias en las que sucede su muerte las que primero debemos considerar para comenzar a comprender el particular lugar que ocupó en la galería de próceres nacionales. En el primer apartado, ponemos el foco en los rituales fúnebres dedicados a Belgrano en 1820 y 1821, como un primer momento de plasmación de modos de representación del héroe, la asignación de virtudes y atributos, la exaltación de sus principales actos y la manera de lidiar con sus errores y fracasos. En el segundo apartado, analizamos la poesía patriótica neoclásica y romántica como medio a través del cual se transmitieron entre generaciones esas representaciones y valores atribuidos a Belgrano hasta que en la década de 1850 esa memoria devino en historia en la Biografía de Belgrano y la Historia de Belgrano, que Mitre publicó en 1857 y 1859. Ese fue el comienzo del tercer momento, en el que la historia de Belgrano comenzó a coincidir con la historia nacional, a partir de la unificación política de 1861. Desde allí, hasta la inauguración de su monumento en 1873, se privilegió su asociación casi exclusiva a la creación de la bandera nacional, elevada a su condición de 
principal símbolo de unidad de un país que durante los primeros cincuenta años había estado dividido.

\title{
La muerte del héroe, cuando Buenos Aires más lo necesitaba
}

\begin{abstract}
“Día 20 del presente mes de junio, A las siete y media de la mañana de este día hizo un año que perdió Buenos Aires a su más virtuoso y obediente hijo el brigadier general D. Manuel Belgrano. Hizo un año que a las pocas horas de tan melancólico suceso se disolvió la representación de la provincia por el nombramiento de gobernador que hicieron las milicias del Lujan en la persona del brigadier general D. Estanislao Soler". ${ }^{2}$
\end{abstract}

Así titulaba El Argos de Buenos Aires el número del 23 de junio de 1821 e inauguraba, sin saberlo, los homenajes a Belgrano que valoraban como principales atributos la virtud y la obediencia; pero, sobre todo, elaboraba la asociación de dos acontecimientos que en 1876, cuando se publicó la tercera edición de la Historia de Belgrano y de la Independencia Argentina, servirían a Bartolomé Mitre como el punto de llegada de la primera etapa de la independencia y el de partida en la construcción de una nueva nación: la muerte del héroe y la disolución de la unidad nacional, en el clímax de la crisis política posrevolucionaria que la historia recordaría como "la anarquía del año $X X^{\prime \prime}{ }^{3}$

Un año antes, esa asociación todavía no había sido elaborada y el fallecimiento de Belgrano a las 7.30 de la mañana del 20 de junio pasó desapercibido más allá de su círculo más íntimo. La Gaceta de Buenos Aires no publicó nada al respecto. La "ingratitud" fue denunciada por Fray Francisco María Castañeda en su periódico el Despertador teofilantrópico del 12 de agosto de 1820, "Porque es un deshonor a nuestro suelo/Es una ingratitud que clama al cielo/[...]/Del triste funeral pobre y sombrío/Que se hizo en una iglesia junto al río/En esta capital al ciudadano/Brigadier general Manuel Belgrano...", quien había servido con sus nobles virtudes y sacrificios por diez años a la patria, hoy hallaba desinterés e ingratitud. Tampoco Juan José Beruti dejó registro del

2 El Argos de Buenos Aires, núm. 7, 23 de junio de 1821. Junta de Historia y Numismática Americana (1831). Reimpresión Facsimilar, Buenos Aires: Atelier de Artes Gráficas Futura. Las posteriores menciones a este periódico remiten a esta misma cita.

${ }^{3}$ Mitre, Bartolomé (1876-1877). Historia de Belgrano y de la independencia Argentina, Buenos Aires: Imprenta y Librería de Mayo. 
evento en su diario y sólo lo recuperó como adenda al finalizar el año en la que justificaba la ausencia de honores fúnebres: "por las convulsiones, que desde su fallecimiento han sobrevenido a esta ciudad, y no tener el Cabildo fondos con que costearlo...". ${ }^{4}$

A partir de la década de 1850, una y otra vez se recordaron los versos de Castañeda como prueba del descuido que signó la muerte del héroe. Más adelante analizaremos las razones por las cuáles esa muerte en la pobreza y el olvido se fue convirtiendo en uno de los motivos principales en la construcción de su imagen pública. Pero en aquel momento, más que el olvido fue la crisis política la que provocó la ausencia de funerales públicos. Castañeda acusaba a la Gaceta por no haber publicado la noticia de su muerte, pero el periódico había anunciado pocos días antes que el gobierno le concedía al general la suma de 500 pesos para cubrir los gastos ocasionados por su enfermedad, en mérito de los servicios que había prestado y de la gravedad de su situación. ${ }^{5}$ Mientras que el 21 de junio publicaba un aviso en el que se anunciaba que se hallaban en venta por 4 reales retratos de San Martín y Belgrano, lo que puede ser una prueba de que era buen negocio la venta de la imagen de figuras que el público podía atesorar o exhibir (Munilla, 2010: 111). ${ }^{6}$ De modo que, en pocos días, entre la asignación de los fondos y su muerte, la atención se había desviado a problemas más urgentes derivados de la ausencia de una autoridad legítima y de la presión de las fuerzas federales que el 28 de junio, mientras se realizaban los austeros funerales, derrotaron a las de Buenos Aires en la Cañada de la Cruz.

Un año después, una vez que cesaron las "convulsiones de esta provincia", Beruti registraba con detalle en su diario los funerales "que correspondían al carácter y a los méritos del general Belgrano". ${ }^{7}$ En 1821 las circunstancias habían cambiado notablemente. Buenos Aires había recuperado su estabilidad política interna con el gobierno de Martín Rodríguez y comenzaba a afianzar sus relaciones con las provincias. De todos modos, el "desinterés" que había denunciado el Despertador Teofilantrópico no puede atribuirse exclusivamente a las circunstancias políticas que rodearon su fallecimiento. Puede haber contribuido también la falta de interés en fundamentar en su imagen alguna de las alternativas políticas que se disputaron el poder en Buenos Aires durante esos días. En cambio, eso sí

\footnotetext{
${ }^{4}$ Beruti, Juan José (1960). “Aumento a este año de 1820”, en Biblioteca de Mayo, T. IV, Buenos Aires, p. 3938.

${ }^{5}$ Gaceta de Buenos Aires, núm. 7, miércoles 14 de junio de 1820. Junta de Historia y Numismática Americana (1915). Gaceta de Buenos Aires, Reimpresión Facsimilar, T. VI (1820-1821), Buenos Aires: Compañía Sud-Americana de Billetes de Banco, p. 197. Las posteriores menciones a este periódico remiten a esta misma cita.

${ }^{6}$ Gaceta de Buenos Aires, núm. 8, miércoles 21 de junio de 1820, pp. 199-202.

${ }^{7}$ Beruti, Juan José (1960). “Aumento a este año de 1820", p. 3944.
} 
sucedería un año después, no por recuperarse en ese momento más propicio sus ideas o sus principales victorias militares sino lo que representaba para una Buenos Aires que se reorganizaba como provincia autónoma a la par que la ciudad comenzaba a recuperar su prestigio con relación al resto de las capitales de provincia. Esa fueron las circunstancias en las que Belgrano se convertiría en un símbolo de la suerte de Buenos Aires: virtuoso y obediente, el mejor de sus hijos había muerto el mismo día en el que la antigua capital virreinal y de las Provincias Unidas del Río de la Plata caía sumida en disputas internas y los caudillos fratricidas del litoral le imponían sus condiciones.

El 18 de julio de 1821, la Gaceta informaba que por orden del Cabildo y el gobierno de Buenos Aires, el domingo 29 de julio se realizaría en la Catedral el funeral dedicado a honrar “...la memoria del Excelentísimo Sr. brigadier D. Manuel Belgrano, capitán general de provincia, y general en jefe del ejército auxiliar del Perú; ilustre hijo de Buenos Ayres; ciudadano virtuoso; militar valiente; fiel amigo de su patria, y generoso defensor de la causa americana". ${ }^{8}$

Ese día los comercios permanecieron cerrados y se suspendieron las funciones de teatro. Al amanecer había sonado un cañonazo en la Fortaleza, que se repitió cada cuarto de hora hasta las 4.30 de la tarde, cuando finalizaron las exequias a las que asistió "un inmenso pueblo de todas la clases". 9 Las formaciones militares, el tronar de los cañones desde la madrugada de ese día y la exhibición de las banderas tomadas al enemigo, interpoladas con fusiles y espadas, eran símbolos de sus triunfos y de sus servicios militares que reforzaban su figura de patriota y héroe guerrero. ${ }^{10}$ Posteriormente, al finalizar los homenajes cívico-militares y religiosos, se llevó a cabo un banquete en la casa de Sarratea al que asistieron "80 ciudadanos notables de todas las clases y carreras", con la presencia del gobernador Martín Rodríguez y el secretario Bernardino Rivadavia, quien pronunció "un breve y tocante discurso sobre el mérito y genio original con el que el general Belgrano había dirigídose con paso firme a la libertad de su patria", luego se brindó y se acordó solicitar al gobierno que la primera ciudad que se funde en la provincia lleve el nombre de Belgrano. ${ }^{11}$ La intención era evitar que su memoria se perdiese en el olvido y en cambio promover que la nación recogiera su herencia como ejemplo para las nuevas generaciones. Con ese mismo fin, el gobierno decretó que se designara

\footnotetext{
${ }^{8}$ Gaceta de Buenos Aires, 18 de julio de 1821, pp. 561-566.

${ }_{9}^{9}$ Gaceta de Buenos Aires, núm. 66, 1ํ de agosto de 1821, p. 566.

10 "Todo se hizo con la mayor grandeza, y mucho más la iglesia que estaba soberbiamente adornada". Beruti, Juan José (1960). "Aumento a este año de 1820", p. 3944.

${ }^{11}$ La Gaceta de Buenos Aires, 1ํ de agosto de 1821; y El Argos de Buenos Aires, núm. 15, 31 de julio de 1821.
} 
con su nombre la calle en la que se hallaba la casa de sus padres, en la que falleció. ${ }^{12}$

La descripción de los rituales fúnebres que organizaron los poderes públicos en 1821 tiene la intención de mostrar que muy lejos se estaba del descuido y desinterés de un año antes y que quedó grabado en la tradición y la memoria reconstruida a partir de la mitad del siglo XIX. Por otro lado, algunos de los homenajes intentaron distinguirse de los del Antiguo Régimen en el modo de representar al héroe y de transmitir a las generaciones futuras su herencia. Ese era el sentido que buscaba la fundación de un pueblo en su nombre, que se fundamentaba en la distinción entre los grandes monumentos que se erigieron a la memoria de tiranos y conquistadores, y el que correspondía al honor de un ciudadano virtuoso y general de los ejércitos que lucharon por la creación de un gobierno libre: “No son monumentos los que deben erigirse al hombre de bien, patriota virtuoso, al amigo, al defensor de los hombres, y al que solo paso por la tierra haciendo beneficios [...], ningún monumento parece más digno de su gloria, ni más conforme al carácter de su genio, que el de consagrarle la primera ciudad que se levantase en los campos del Sud de nuestras provincias" ${ }^{13}$

Ese modo de representar a Belgrano pretendía hacer evidentes las diferencias respecto de otros símbolos y figuras alegóricas de inspiración neoclásica que abundaron durante los funerales. Sobre todo aquellas que lo instalaban en el Olimpo junto a los dioses griegos o dialogando con la virgen María de las Mercedes, como sucedía en la Oda que le dedicó Joaquín Culebras en el teatro El Coliseo. El contraste fue la oportunidad utilizada por El Argos de Buenos Aires para debatir acerca de los modos de homenajear a los héroes cívicos y militares de la emancipación: “Los dioses del paganismo se hallan absolutamente fuera de su lugar en todo argumento moderno y es imposible que vuelvan a producir el más mínimo efecto en nuestros teatros, a menos que no sea en estilo burlesco". ${ }^{14}$

La polémica reabría el tema en torno a los homenajes dedicados a los hombres de Estado, pero la pregunta fundamental es si estamos en un momento en el que se buscaba imponer un estilo moderno a los tributos

\footnotetext{
12 Por lo pronto, en ese momento el registro material de su memoria se reducía a una "alegórica y encomiástica a los menes del general Belgrano" en la vereda ancha de la tienda de D. Miguel Ochagavía. El Argos de Buenos Aires, núm. 19, martes 14 de agosto de 1821.

${ }^{13}$ El Argos de Buenos Aires, núm. 19, martes 14 de agosto de 1821, p. 116.

${ }^{14}$ El Argos de Buenos Aires, núm. 20, 18 de agosto de 1821, p. 124. Joaquín Culebra y Castañeda defendieron la referencia a los dioses en una "ficción poética" apelando a las reglas de un género en el que las alegorías de la sabiduría, la valentía y la soberanía solían utilizarse para referir a los atributos del héroe. La Loa parece haber sido escrita por Castañeda, dedicada al gobernador Martín Rodríguez quien, a su vez, la mando imprimir. El Desengañador gauchipolítico arrepentido, núm. 25, Buenos Aires, agosto 25 de agosto de 1821, pp. 518-530.
} 
dedicados a los héroes cívicos y militares republicanos que los distinguiera de las formas utilizadas durante el Antiguo Régimen para las celebraciones, homenajes y funerales. La respuesta es negativa si nos atenemos al estilo que confirió el Cabildo a los funerales de Belgrano, pero no lo era para los rivadavianos que habían llegado al gobierno el 18 de julio de 1821 y cuyas ideas de reformismo ilustrado expresaba El Argos de Buenos Aires, que inscribía la crítica a la oda de Joaquín Culebras en un contexto más general de secularización del espacio público en el que el periódico ministerial abogaba por el establecimiento definitivo de un gobierno representativo en Buenos Aires, cuya realización confiaba a hombres de honor y virtud (Myers, 2004: 39$63) .{ }^{15}$

Ese es también el sentido que predomina en el elogio fúnebre, tan diverso al de Culebras, que le dedicó a Belgrano José Valentín Gómez y que serviría de modelo para mucha de las odas, elegías y canciones que se le ofrecieron durante esos meses. Las palabras fúnebres leídas en la Catedral tenían la intención de reparar el silencio que había rodeado su muerte un año antes $\mathrm{y}$, al hacerlo, resumir las acciones y los atributos que acompañarán a Belgrano de aquí en más, pero sobre todo que contienen los rasgos clásicos de la vida del héroe. ${ }^{16}$

En primer lugar el olvido y descuido de sus contemporáneos: “Disculpa a tus compatriotas, ilustre sombra de Belgrano, si recién se han acercado a derramar lágrimas sobre el sepulcro, que encierra tus cenizas". El hijo dilecto de Buenos Aires moría cuando la ciudad más necesitaba "de tu presencia, de tu ejemplo y de tus virtudes".

En segundo lugar, la partida de Buenos Aires y las acciones realizadas a su servicio no se valoraban por sus victorias, ya que la fortuna "las más de las veces le reusó sus locos favores", sino porque fue superior a los fracasos, "supo sacar de las desgracias más ventajas que un genio menos elevado habría conseguido del triunfo". Así, las derrotas de Vilcapugio y Ayohuma son más relevantes que sus victorias en Tucumán y Salta, porque "su alma estaba templada en la fragua de todos los infortunios". Es su capacidad para atravesar las desgracias y continuar su camino hacia un objetivo la que lo hace merecedor del nombre de héroe por encima del resto de los hombres $\mathrm{y}$, sobre todo, de aquellos que se arrogan inmerecidamente ese nombre "pero luego las calamidades extinguen ese fuego". También Fray Cayetano Rodríguez recuperó ese tópico ${ }^{17} \mathrm{y}$, un año después, era reiterado por Bernardino Rivadavia en el

${ }^{15}$ El Argos de Buenos Aires, núm. 15, 31 de julio de 1821, p. 95.

${ }^{16}$ Gómez, José Valentín "A la memoria del Brigadier general D. Manuel Belgrano con ocasión de sus funerales", en Gaceta de Buenos Aires, miércoles 1 de agosto de 1821.

17 Elogio fúnebre de Fray Cayetano, en Otero, José P. (1918). Fray Cayetano, Buenos Aires: Librería del Colegio y Cabaut \& Cia Editores. 
banquete a la memoria de Belgrano, cuando señaló en referencia a la expedición al Paraguay, que aun en la derrota "el general supo triunfar". ${ }^{18}$

En tercer lugar, sus atributos. Sobre todo la obediencia y patriotismo, que le permitieron sostener sus posiciones en inferioridad de condiciones y casi sin recursos en Salta y Tucumán: "Cuando el desaliento ocupaba nuestros ánimos, y era un atrevimiento la esperanza". A ellos se sumaba otro atributo que será fundamental para la construcción definitiva del personaje, su consagración al servicio de la patria sin ambición, sin aspiraciones, sin interés personal y sujeto al designio de la divina providencia.

En cuarto lugar, el retorno del héroe derrotado "que deseaba morir en el seno de su familia", regresaba solo, acongojado y pobre, recorriendo el mismo camino que "en otros tiempos había atravesado lleno de gloria, cubierto de honor, y colmado de aplausos". Belgrano condensaba todas las características del héroe no porque fuera un estratega imbatible en batalla, un hombre de ideas pragmáticas adecuadas a su tiempo, un republicano convencido sino precisamente porque más allá del éxito y la gloria hizo lo que debía hacer y no obtuvo de ello sino ingratitud. Mitre ofrecía así un espejo en la que la propia Buenos Aires podía mirarse, convencida de que sus esfuerzos por la causa de la libertad no habían sido valorados por las desagradecidas provincias: "todas las satisfacciones de la gloria y la grandeza, y todos los ultrajes de la fortuna: un jefe esforzado, que con dos insignes victorias salva a los pueblos del furor de los tiranos: un general desairado, que regresa como un fugitivo". La apoteosis lo consagra como héroe exclusivo de Buenos Aires y de la América toda, ya no de las provincias que le dieron la espalda cuando regresaba enfermo a su casa natal en medio de la guerra civil.

Durante las primeras dos décadas revolucionarias los funerales dedicados a Manuel Belgrano solo pueden compararse con los que se le tributaron a Manuel Dorrego casi diez años más tarde y que, como en el caso de Belgrano, se realizaron un año después de su muerte (Di Meglio, 2014: 360). De todos modos, las diferencias entre ellos resultan evidentes. Belgrano se encontraba en el ocaso de su vida política y militar y se hallaba asociado a un grupo político cuyo proyecto de organización nacional había fracasado. En ese contexto, su experiencia y su prestigio ya no contaban demasiado y cuando volvió a Buenos Aires se hallaba enfermo y marginado de la política porteña. Por su parte, al momento de su muerte Dorrego era el gobernador electo, líder del partido federal y el político más popular de Buenos Aires. Su fusilamiento en Navarro el 13 de diciembre de 1828 convirtió a sus funerales en un acontecimiento político de enorme relevancia y se replicó en diversos pueblos de la campaña. Por otro lado, los funerales de Dorrego, digno de un jefe de

${ }^{18}$ El Argos de Buenos Aires, núm. 46, 26 de junio de 1822, p. 188. 
Estado sumamente popular y cargados de simbología republicana y federal, contrastaban con el tono nostálgico que predominó en los funerales a Belgrano, como una de las glorias de una revolución que había dado paso a una desconcertante anarquía.

Finalmente, Dorrego remitía también a un orden más nacional y así lo reflejaba el mensaje escrito en el pedestal del catafalco de la Catedral: "Descanza/ mientras la República Argentina/ Preconiza tus servicios". ${ }^{19}$ En el caso de Belgrano, su representación como héroe local se observa no solo en sus funerales sino también en la percepción que se tenía de él en las provincias. Pocos meses antes de su muerte, el 8 de enero de 1820, Francisco Ramírez envió un oficio dirigido al gobierno de Buenos Aires en el que lo conminaba a que cumpliera con los requerimientos para poner fin a la guerra y se persuadiera de la imposibilidad de destruir las legiones de los libres: "Con la misma serenidad que supimos castigar a los Balcaceres, Diaz Veles, Biamones, y Belgranos, esperamos a los Rondeaux, San Martines, y Cruzes (sic)" ${ }^{20}$

Durante las décadas siguientes, el carácter porteño de Belgrano y la asociación de su muerte a la crisis política que puso fin a la autoridad nacional en 1820 se fue consolidando, así como el reconocimiento de sus principales atributos, en el contexto de la ausencia de consenso respecto a quienes merecían ser reconocidos como héroes de la Revolución de Mayo. ${ }^{21} \mathrm{Al}$ mismo tiempo, se percibe en la construcción de su imagen pública la preponderancia de los poetas y publicistas ilustrados vinculados con el grupo rivadaviano. Finalmente, en la multitud de elogios fúnebres, banquetes, odas y brindis de la primera mitad de la década de 1820 no se hacía mención a la creación de la bandera o a los símbolos de la nueva nación, pero más importante es que no se destacaba su contribución al derrocamiento de la monarquía y al triunfo de las ideas republicanas.

\footnotetext{
${ }^{19}$ Juan José Beruti, que había condenado el fusilamiento de Dorrego, destacaba en su diario que nunca se habían celebrado funerales con tan “...magnífica pompa, nunca vista en Buenos Aires, y que mejor ya no puede ser, que ni a un príncipe se le puede hacer mejor". Beruti, Juan José (1960). "Aumento a este año de 1820", pp. 4041-4046.

20 "Toda esa gran maza, con que se nos amenaza, no hara más que aumentar los males de la patria , y cubrir de oprobio al ejercito de Buenos Ayres, dejándonos sin poder para resistir las invasiones extranjeras", Ramírez, "Oficio del general Ramírez al Exmo. Cabildo de esta Ciudad", Gaceta de Buenos Aires, Extraordinaria de la tarde, 16 de febrero de 1820, p. 51.

${ }^{21}$ Es importante señalar que todo ello sucede en el contexto de la ausencia de consenso para instaurar monumentos permanentes con el nombre de los héroes. Los argumentos fueron variados y, entre ellos, se incluyó la negativa a aceptar héroes porteños en menosprecio de las provincias, como sucedió en el debate que se produjo en 1826. Diario de Sesiones del Congreso nacional Constituyente de las Provincias Unidas del Río de la Plata, núm. 147, 9 de junio de 1826 y núm. 148, 10 de junio de 1826 (Wassermann: 2008).
} 


\section{Un modelo de virtud para las generaciones futuras}

En 1824, La Lira Argentina recogió versos, odas, sonetos y elegías que se habían publicado entre 1810 y 1822, entre ellos los que tuvieron como inspiración los funerales de Belgrano. Si bien no exhaustiva, los 2.000 ejemplares publicados contribuyeron a la circulación y trasmisión intergeneracional de modos de representación del héroe, con sus defectos y virtudes, de los principales acontecimientos de la Revolución y la independencia, y de la representación de Mayo como momento fundacional de una nueva nación.

No era otro el fin que le auguraba el editor de La Lira: "redimir del olvido todos los rasgos del arte divino con que nuestros guerreros se animaban en los combates en la gloriosa guerra de la independencia". Pero el propio gesto de recordar un pasado reciente revela la distancia que comenzaba a separarlo de las jóvenes generaciones, que justificaba la necesidad de rescatarlo del olvido. Ello se percibe particularmente en los versos dedicados a los funerales de Manuel Belgrano entre 1821 y 1822, en los que se torna evidente la conciencia del fin de la Revolución y el comienzo de un periodo menos heroico en el que el horizonte de futuro se había modificado dramáticamente. El momento de inflexión fue la crisis política e institucional del año 1820, cuyo clímax coincide con la muerte del héroe, que funcionaría como bisagra entre los acontecimientos cívico-militares del pasado reciente (de los que se destacaba la heroicidad de la lucha por la emancipación y la independencia) y la etapa menos virtuosa de las guerras civiles, que provocaron la fragmentación política de las Provincias Unidas del Río de la Plata y la pérdida del lugar de privilegio que Buenos Aires había alcanzado en la etapa anterior. Por ello, sus destinatarios eran sin duda los contemporáneos, pero sobre todo las generaciones futuras que debían hallar en aquella época tan diferente de las que ahora les tocaba vivir un modelo en el que inspirarse.

La función política e histórica que los editores y el gobierno le asignaban a la poética patriótica era compartida también por los poetas, que se reservaban para sí un lugar de privilegio en la construcción de la memoria colectiva, como lo manifestó Juan Cruz Varela en "A la libertad de Lima", en el que pregunta qué sería del héroe sin los versos que los sobreviven: "Sin las musas/Un héroe al fin no es héroe; que perdido/debe quedar su nombre en las confusas/ tinieblas del olvido" ${ }^{22}$ Hay algo de perpetuación de la memoria, de comunicación entre generaciones y también de invención en la pregunta en torno a qué sería de los héroes y sus hazañas sin los poetas que junto a los dioses eran los únicos que trascendían el tiempo.

${ }^{22}$ Varela, Juan Cruz "Por la libertad de Lima, el 10 de julio de 1821", en La Lira Argentina o colección de piezas poéticas, dadas a la luz en Buenos Aires durante la guerra de su independencia, Biblioteca Universal Virtual, pp. 442-452. 
El poder de plasmación de la poesía patriótica y su contribución a la construcción de un imaginario colectivo fue destacado por Juan María Gutiérrez al señalar la función política de los versos que habían alimentado las lecturas de su generación: “es de notarse la fe que existía por aquellos días en la influencia del verso sobre la opinión pública [...] la influencia saludable de la palabra rimada sobre la sensibilidad y la imaginación de la masa del pueblo" ${ }^{23}$ Por otra parte, su perdurabilidad estaba asegurada por su valor como archivo de una época heroica, que le atribuyeron sus compiladores, pero también Florencio Varela para quien: "Entre nosotros casi toda la literatura destinada a vivir más allá del día, está limitada a la poesía: en ella está nuestra historia, en ella nuestras costumbres, en ella nuestras creencias, ideas y esperanzas" ${ }^{24}$

Finalmente, la transmisión intergeneracional se veía favorecida por una poesía que se caracterizaba por la unanimidad en las motivaciones y la uniformidad en su encarnación verbal propia de un seudoclasicismo en el que podían variar los motivos pero no la poética (Barcia, 2001: 109-145). En este sentido, podemos considerar que el valor de los versos no radicaba en su originalidad sino precisamente en lo contrario, la repetición de figuras en la evocación de batallas, sucesos legislativos y el culto a un puñado de héroes: entre los que se destacaban Balcarce, Alvear, San Martín y Belgrano. ${ }^{25}$

De todos modos, la unidad formal de la poesía neoclásica, basada en reglas convencionales que favorecían la uniformidad y la transmisión intergeneracional, no impide que los versos dedicados a Manuel Belgrano adquieran cierta singularidad producto de las circunstancias políticas en las que se produjo su muerte, que habilitan ese sentido de nostalgia de un pasado reciente y, al mismo tiempo, irremediablemente ido. Esa marca de época queda reflejada en el carácter más personal y local que se le confiere a la memoria del hijo dilecto de Buenos Aires, hecho que permite resaltar su figura no solo por sus atributos, sino por las circunstancias en la que se produjo su deceso que tornaron esos atributos más valorables: un militar obediente cuyo patriotismo sin ambición ni interés personal lo motiva a actuar por el bien exclusivo de la patria:

\footnotetext{
23 "La literatura de mayo", en Gutiérrez, Juan María (1979). La literatura de mayo y otras páginas críticas, Buenos Aires: Centro Editor de América Latina. Apareció por primera vez en la Revista del Río de la Plata, 8, 1871.

${ }^{24}$ Florencio Varela, citado por Gutiérrez, Juan María (1979). La literatura de mayo..., p. 46.

${ }^{25}$ Ese es el sentido que reconoce Florencio Varela en el informe de la Comisión clasificadora del certamen poético de 1841 con referencia a una poesía escrita por quienes considera los "sacerdotes encargados de las festividades patrias ", pero que "esto y nada más podía pedirse a los que tenían fuego en la mente, patriotismo en el corazón", Informe de la Comisión Clasificadora del Certamen poético de Mayo, Montevideo, 1841, en Escritos políticos, económicos y literarios del dr. Florencio Varela (1859). Buenos Aires: Imprenta del Orden, pp. 70-81.
} 
"Las causas de olvidarnos de Belgrano/ Son muy justificadas en lo humano", se lamentaba Castañeda días después de su muerte, que asimilaba a la caída de Buenos Aires. Las mismas circunstancias aparecen en el poema de Esteban de Luca: “Fue de su muerte la Discordia impía/ [...] /Perdió entonces la hermosa Buenos Aires/ [...] Aun más plagas/ Nos restan que sufrir/Pues que no existe Belgrano entre nosotros...". De ello surge el vacío que queda tras su desaparición: “¿Cómo te fuiste, y huérfana dejaste/ Tu amada patria, que a la vez libraste/Con los cortantes filos de tu azero?" (Anónimo); “Faltas, Belgrano, faltas", se lamentaba Juan Cruz Varela, que interpelaba a la muerte que se lo llevó y dejaba a Buenos Aires abandonada: "Hora sin gefes, sin virtud, sin freno/ La obediencia perdida/...". La misma falta, la misma ausencia, la misma incertidumbre expresa Lafinur, "La patria desolada el cuello tiende/ Al puñal parricida que le amaga/ [...]/ El inocente pueblo, ilustre un día,/ A la angustia entregado;[...]/ y ¿ora faltas Belgrano? [...]/ ¿Y diez años de afán! [...] ¿Todo se pierde!/ Tu zelo, tu virtud, tu arte, tu genio,/ Tu nombre en fin, que todo lo comprende/..."; ${ }^{26}$ y Vicente López y Planes: “De tu alto brazo, de tu recto pecho/ Cuando se vio ella más necesitada/ Que en hora tan terrible y malhadada" ${ }^{27}$

No es que estén ausentes las notas aprendidas en los ejercicios de retórica realizados en los cursos del Colegio San Carlos. Pero es la muerte en el momento "que más Buenos Aires lo necesitaba" la que no podía asimilarse a las figuras disponibles en los héroes clásicos de la latinidad. Así la unidad formal de la poesía patriótica y la imitación de modelos que despersonalizaban los versos y los dotaba de rasgos universales en la caracterización de los héroes y los acontecimientos de la Revolución, adquieren en los versos dedicados a los funerales de Belgrano un tono localista, personal y situado, que se difundió a través de La Lira que Esteban Echeverría cargó en su equipaje en su viaje a Europa, de donde regresaría como principal promotor del romanticismo (Barcia, 1982: LXXXII).

Después de la publicación de La Lira, la poesía patriótica de inspiración neoclásica o romántica continuó evocando el espíritu de mayo, sus héroes y principales triunfos, sobre todo Salta, Tucumán, Maipú y Chacabuco, con una

\footnotetext{
${ }^{26}$ Fray Francisco de Paula Castañeda, "Señor Teofilantrópico", en el Despertador Teofilantrópico, Buenos Aires, sábado 12 de agosto de 1820, núm. 17, p. 260; Esteban de Luca, "A la muerte de Belgrano. Del señor Brigadier de los ejércitos de la patria y general de los ejércitos del norte y Perú", pp. 285 y ss.; Anónimo, "Sonetos que expresan el carácter y mérito del General Don Manuel Belgrano", p. 297; Juan Cruz Varela (atribuida por P. Barcia), "Canto a la muerte del Sr General D. Manuel Belgrano", pp. 298-302; Juan Crisóstoma Lafinur (L.C.J.), "A la muerte del general Belgrano", pp. 308-312. Las citas corresponde a La Lira Patriótica Argentina, citada. Los datos correspondientes al poema de Castañeda son del autor, el resto son tomados de Barcia (1982). En todos los casos se mantiene la grafía original. 27 "Soneto elegíaco", en El Argos de Buenos Aires, 31 de julio de 1821, p. 98.
} 
retórica que reiteraba lugares y figuras ya utilizadas en las primeras décadas. Por su parte, la asociación de Belgrano y la bandera -el símbolo de la unidad de un pueblo dividido- compartieron, aunque separadamente, el protagonismo en los versos de los emigrados durante el gobierno de Juan Manuel de Rosas. En cuanto a Belgrano, su presencia era predominante en el acotado círculo de héroes porteños, sobre todo entre los poetas emigrados en Chile y Montevideo. Ascasubi recuperaba en 1844 los personajes de Bartolomé Hidalgo, que en la Montevideo sitiada rememoraban las glorias de la guerra de independencia: "Quiénes hicieron la punta, cuando la patria se alzó", lo interpela Contreras a Chano, que responde resaltando la figura de Belgrano entre ellos: "y mi general BELGRANO/ De quien cuando hacen mención/ Hasta los Pampas, tributan/ Respeto y veneración...!". ${ }^{28}$ Ese mismo año, "Es esta la patria del gran San Martín?", se preguntaba José María Cantilo en los versos compuestos para la celebración del 25 de mayo de 1844 en Montevideo; "Qué es hoy para nosotros esa patria, que produjo un Belgrano y un Moreno, un San Martín, un sabio Rivadavia,...", indagabacon nostalgia de emigrado Juan Gualberto Godoy, en El 25 de Mayo de 1849; mientras que Claudio Mamerto Cuenca, lo instalaba "sobre su trono de gloria majestuoso/al mismo Marte enseña/ que el hablar a Belgrano no desdeña", en la Oda a la jura de la Independencia. Por su parte, en su poema A mayo, Luís L. Domínguez colocaba a Belgrano junto a San Martín y Bolívar: "Belgrano, tu alto nombre/ escrito está en los templos;/ tus hechos, ¡Oh grande hombre!/ serán bellos ejemplos/ que nunca ha de morir;/..."; mientras que en $A$ mayo, de 1844, distinguía a los héroes en dos niveles, en cuya cúspide se encontraban Bolívar, Belgrano y San Martín, a quienes “Bien conoce el universo"; y José Mármol en Cantos del peregrino, apelaba a Belgrano para acusar a quienes en Buenos Aires habían apoyado al "tirano" Juan Manuel de Rosas: "Corred hasta las santas Catedrales,/ A vuestros pies la lápida se quiebre;/ Y llevad en el cráneo de Belgrano/ Sangre de vuestros hijos al tirano"; y en 1849, “¡Oh, no! La tiranía si ha venido/ no ha triunfado en la patria de Belgrano" rezaba el verso en el que el poeta se situaba "de pie, y al lado de tu noble tumba", en Al 25 de mayo de 1849. Finalmente, en su poema Rosas El 25 de mayo de 1850, lo reclamaba con desesperanza de quien percibe que el fin de la tiranía estaba lejano: "La justicia se acerca religiosa/ a llamar en la tumba de Belgrano; y ese muerto inmortal le abre su losa/ alzando al cielo su impotente mano". ${ }^{29}$

\footnotetext{
${ }^{28}$ Hilario Ascasubi asume la autoría de estos versos en 1853. La versión original aparece sin firma de autor en "Recuerdos gauchi-patrioticos, tenidos por los paisanos Ramón Contreras y Fernando Chano, en las trincheras de Montevideo el 25 de mayo de 1844", en Cantos de Mayo. Leídos en la sesión del Instituto Histórico-Geográfico Nacional el 25 de Mayo de 1844 (1844). Montevideo: Imprenta de El Nacional, pp. 180-212.

${ }^{29}$ Miri, Hector F. (1960). Antología poética de mayo, Buenos Aires: Ediciones Antonio Zamora, p. 134.
} 
De todos esos versos, se destaca el de un joven Bartolomé Mitre, que se distanciaba parcialmente de los lugares comunes en su poema Al 25 de Mayo de 1844, no por las imágenes que utilizaba, que abrevaban directamente de la poesía neoclásica con citas a Juan Cruz Varela, Vicente López y Planes y Rivera Indarte; sino porque su inspiración excede las motivaciones antirrosistas que tienen los versos patrióticos de los emigrados para trazar un cuadro más general del proceso histórico abierto por la revolución americana y proyectarse al porvenir. Las notas, incluidas al final de los versos en la edición de los Cantos a Mayo de 1844, los hacen descansar en una interpretación histórica del proceso revolucionario atravesado por "el pueblo en el que nació Belgrano" que se sostiene sobre un conjunto de ideas precisas: la proyección americana de la revolución, que se extiende del norte al sur del continente; la divina providencia como motor de la historia; el carácter democrático de la revolución que se inició en Buenos Aires "sin lanzas ni fusiles"; el carácter original de la revolución de Buenos Aires, la Atenas de América que no se destacaba por haber sido la primera sino "por su objeto, por su poder, por sus resultados, y su influencia en los destinos de la América toda, en cuya balanza puso su inteligencia, su oro, su sangre, y su espada...".

En tanto que la bandera era uno de los símbolos más mencionados en la poesía patriótica marcada por el carácter faccioso que imprimía el conflicto entre el rosismo y los emigrados, siempre como referencia de unidad por encima de los partidos: "dos bandos fratricidas les llevan en sus lanzas/ Mañana en torno suyo se abrazarán también", concluía Juan María Gutiérrez su poesía La bandera de Mayo, que escribió en Valparaíso para la celebración del 25 de mayo de $1845 .^{30}$

De todos modos, como ha señalado Tulio Halperin Donghi, no aparece asociación alguna entre el héroe de Buenos Aires y el símbolo patrio. Ni siquiera el propio Belgrano la mencionaba como un acto memorable en su autobiografía de 1814. La primera mención a la jura en el Río Pasaje la realizó Arenales en 1833, sin demasiada repercusión. Todavía en 1854, Mitre no hacía mención a la creación de la Bandera por Belgrano en el poema La tumba del poeta, en el que recuperaba versos de la oración fúnebre de Cayetano Rodríguez de 1821 para instalar a Belgrano en la cúspide de la constelación de héroes americanos: “Tus cantos serán oídos/ En el pueblo americano,/ Como el nombre de Belgrano,/ De Bolívar, San Martin,...". ${ }^{31}$ Todo cambia en 1855, cuando se publican las exitosas Memorias de José María Paz, en la que se recupera el

${ }^{30}$ Gutiérrez, Juan María (1960). “La bandera de Mayo”, Antología poética de Mayo, Buenos Aires: Ediciones Antonio Zamora, pp. 94-95.

${ }^{31}$ Mitre, Bartolomé (1891 [1854]). “En la tumba de un poeta”, Rimas, Buenos Aires: Lajouane, pp. 175 y ss. 
episodio de la jura con el fin de poner en cuestión el significado que le había otorgado Arenales en 1833 como un antecedente de la independencia.

\section{El Héroe nacional y republicano, tan solo un simple y buen ciudadano}

La crisis del año 1820, que en la poesía patriótica de Buenos Aires había provocado el desplazamiento de un patriotismo regional y americano a uno predominantemente local, favoreció su identificación con la situación que vivió la provincia después de la revolución del 11 de septiembre 1852, cuando se separó de la Confederación Argentina, que bajo el liderazgo de Justo José de Urquiza consolidó su organización constitucional. En ese nuevo momento bisagra, para Buenos Aires y para el resto de las provincias, el año 1820 ofrecía un espejo en el que mirarse y a partir de aquella experiencia dirimir las alternativas que tenía por delante ante el riesgo de una nueva disolución nacional y con Buenos Aires asediada una vez más por un caudillo del litoral.

A partir de la batalla de Caseros, en febrero de 1852, tres relatos van a confluir a partir de necesidades diversas pero convergentes: la bandera como símbolo de unidad alternativo al rojo punzó del rosismo, convertido en símbolo de una época, una forma de gobierno y un estado de civilización contrario al progreso; ${ }^{32}$ Belgrano, como héroe cuyas virtudes republicanas y patriotismo desinteresado van a ser asimilados a los de Buenos Aires en su lucha contra la Confederación; y la búsqueda en la ciudad de Rosario de un antecedente en la época revolucionaria, que le otorgue un pasado ilustre a la ciudad "fenicia" que crecía por impulso del comercio exterior y el aluvión migratorio de la segunda mitad del siglo XIX.

En cuanto a Belgrano, los atributos que se le habían conferido desde su fallecimiento se habían consolidado. Incluso su rostro, que durante años circuló retratado por Boicard, Carbonnier, Gericault, Goulú, Núñez de Ibarra, Adrienne Macaire Bacle y Rugendas, adquiría definitivamente el carácter que le había

\footnotetext{
32 Ese significado de símbolo privilegiado de la unidad nacional le otorgó Urquiza en su discurso en el Congreso General Constituyente: “La geografía, la historia, los pactos, vinculan a Buenos Aires al resto de la nación. Ni ella puede existir sin sus hermanas, ni sus hermanas sin ella. En la bandera argentina hay espacio para más de catorce estrellas; pero no puede eclipsarse una sola"; y Bartolomé Mitre en el debate contra el acuerdo de San Nicolás en la sala de Representantes de la provincia: “¿No pertenezco a esa comunión, que tiende a organizarse en un cuerpo de nación, y cuya sangre ha corrido unida á la sombra de una misma bandera en todos los campos de batalla de la independencia?". Cfr. Urquiza, Justo José de "Alocución de Justo José de Urquiza, 20 de noviembre de 1852", en Congreso General Constituyente 1852-1854, 6o sesión, s/f, p. 173; Mitre, Bartolomé (1902). “Discurso contra el acuerdo de San Nicolás, 21 de junio de 1852", en Arengas de Bartolomé Mitre, T. 1, Buenos Aires: Biblioteca de La Nación, p. 21.
} 
otorgado el retrato que Casimir Carbonnier realizó en $1815 .{ }^{33}$ No había enigma en su rostro, tal como Tulio Halperin Donghi afirma, sino que es una de las pocas figuras de la Revolución cuyos rasgos se encontraban tempranamente definidos. De hecho, la figura que delinea Carbonnier se encuentra en la base de la mayoría de sus retratos públicos. Al mismo tiempo esa imagen adquiría espesor narrativo en las Memorias del General Paz, que lo tiene como protagonista privilegiado del primer tomo publicado en $1855 .{ }^{34}$

Se ha realizado durante mucho tiempo una lectura sesgada de las Memorias de Paz, sobre todo de las primeras páginas, aislando algunos fragmentos sacados del contexto de un volumen en el que predomina la valoración positiva del personaje. A esa operación selectiva no escapa El enigma Belgrano, que encuentra la clave para resolverlo en la famosa escena en la que San Martín impartía clase de voz de mando a sus oficiales y se vio obligado a amonestar en tres oportunidades a Dorrego, que se mofaba de la ínfima voz de quien fuera su jefe en el Ejército Auxiliar del Perú. Sin embargo, la escena servía a Paz no para humillar a Belgrano sino para demostrar los rasgos del carácter de quien fue su enemigo, Manuel Dorrego. Mientras tanto, del General responsable de los triunfos en Tucumán y Salta no solo destacaba su patriotismo desinteresado, junto con sus atributos cívicos y morales, que se le venían reconociendo desde su fallecimiento y aún antes, sino incluso sus méritos militares, que iban más allá de su apego al orden y la disciplina. En este sentido, no se puede afirmar que es a partir de la Historia de Belgrano escrita por Mitre en 1859 que se construye la imagen del héroe. Las Memorias póstumas de Paz son fundamentales para comprender la instalación pública de la figura de Belgrano en la conflictiva década de la secesión del Estado de Buenos Aires en la década de 1850, por el éxito de las Memorias, por el prestigio de Paz en Buenos Aires al retorno de los emigrados, y por el peso que van a tener en los años siguientes, sobre todo en Mitre, para la interpretación global de la historia de la independencia. ${ }^{35}$

En ellas, si bien cuestiona cierta ligereza de carácter en la apreciación de sus oficiales, los excesos de su disciplina, la escasa preparación militar y los errores cometidos en las derrotas de Vilcapugio y Ayohuma, lo considera el mejor general de la república ${ }^{36}$ hasta la llegada de San Martín a quien superaba en cuanto a su civismo republicano ${ }^{37}$ y en su capacidad para promover el

\footnotetext{
33 Un soneto dedicado a ese retrato afirmaba: "El reposo y la gracia pinta activo,/ son las facciones de Belgrano mismo,/ de aquel finado en la memoria viva"; Anónimo (1993). "Al retrato perfecto del general Belgrano por Moseiur Carbonier", Anales, 6, Instituto Belgraniano, Buenos Aires, pp. 117-118.

${ }^{34}$ Paz, José María (1855). Memorias póstumas, Buenos Aires: Imprenta de la Revista.

${ }^{35}$ Mitre, Bartolomé (1859). Historia de Belgrano, Buenos Aires: Imprenta de Mayo, T. I.

36 Paz, José María (1855). Memorias póstumas..., pp. 158-159.

${ }^{37}$ Paz, José María (1855). Memorias póstumas..., pp. 178-179.
} 
espíritu revolucionario y el mérito de su causa, que habían quedado desprestigiados tras el paso de Castelli. ${ }^{38}$ "Hay más aún que decir en honor del general Belgrano. Hasta que él tomo el mando del ejército se puede asegurar que la revolución propiamente hablando no estaba hecha en esas mismas provincias que eran el teatro de la guerra....". ${ }^{39}$ A tal punto la importancia que le asigna a Belgrano en el norte que considera que fue una gran desgracia su desplazamiento, ya que San Martín lo reemplazó apenas unos meses y ese vacío no pudo ser llenado posteriormente por Rondeau. ${ }^{40}$

Finalmente, es en las Memorias cuando se vincula a Belgrano con el juramento de la bandera nacional en las riberas del Río Pasaje, allí “tuvo lugar la solemnidad del juramento, que recibió al ejército de defender el nuevo pabellón celeste y blanco". La intención era rebatir el significado que le había asignado a ese episodio José Antonio Álvarez de Arenales en 1833, cuando lo consideró una declaración de independencia. ${ }^{41}$ Para Paz, en cambio, solo se trataba del juramento de la bandera del regimiento y no de un símbolo nacional: "Lo que aquellos actos importaban nadie lo desconoce, pero me parece conveniente no confundirlo con la declaración de la Independencia, que no podía declarar un general sin hacerse criminal y constituirse en rebelión en presencia de un gobierno y de un cuerpo deliberante". ${ }^{42}$

El significado de ese episodio divulgado a partir de la obra de Mitre, al que agregó el antecedente del izamiento en las barrancas de Rosario el 27 de febrero de 1812, será clave para otorgar a Belgrano el carácter de héroe nacional. Puede que Paz estuviera en lo cierto, lo que corroboraría que la bandera que se juró en el río Pasaje tenía el escudo de la asamblea del XIII y no era la misma que se había jurado en Rosario el 27 de febrero de 1812. De cualquier modo, lo importante es que de Paz a Mitre, la escena permanecía intacta. Pero respecto al significado del juramento, Mitre decide quedarse con la versión que había dado Álvarez de Arenales en 1833, que se había reactualizado con la reedición de su libro en 1849. En efecto, Mitre se basa en tres fuentes para determinar el significado de lo sucedido el 13 de febrero de 1813 en el río Pasaje -las Noticias

\footnotetext{
38 Paz, José María (1855). Memorias póstumas..., p. 107.

${ }^{39}$ Paz, José María (1855). Memorias póstumas..., p. 55.

40 Paz, José María (1855). Memorias póstumas..., p. 173. En cuanto a sus méritos militares, más adelante discute con Lamas, que responsabiliza a los militares de los males de la historia del Río de la Plata, ya que buscaron entronizar el poder militar. Dice que es válido solo si se hace referencia a los caudillos: Rosas, Quiroga, Artigas, Aldao y López, entre otros, pero no a San Martín y Belgrano: "Las verdaderas ilustraciones militares que ha habido en el Río de la Plata como Belgrano, San Martin, Arenales y otros muchos en nada han perjudicado los progresos del país...", T. III, pp. 159-161.

${ }^{41}$ Arenales, José (1833). Noticias históricas y descriptivas sobre el gran país del Chaco y rio Bermejo, Buenos Aires: Imprenta de halle, pp. 67-68 [Hay una segunda edición en Montevideo, 1849].

42 Paz, José María (1855). Memorias póstumas..., p. 72.
} 
de Arenales, las Memorias de Paz y los Recuerdos del coronel Lugones- ${ }^{43}$ pero lo que determina su interpretación es la inscripción en una trama un poco más larga, que se inicia con el retorno de Belgrano del Paraguay, cuando su figura se destaca en un contexto de crisis política, moral y militar. Belgrano aparece en escena protagonizando tres actos que modelan su imagen asociada a su obediencia al gobierno, el apego a la disciplina y un patriotismo desinteresado. A pesar de sus magros recursos, dona la mitad de su sueldo; y aplica una disciplina rigurosa al orgulloso regimiento de Patricios, que había sido puesto a su cargo. Vencida la rebelión, marcha a Rosario con la misión de levantar baterías sobre el Paraná para controlar la incursión de flotillas españolas. En ese momento toma una decisión cuya intención es fortalecer un espíritu público que en los pueblos se encontraba desmoralizado por las derrotas: “....acelerar la época de la independencia, y o comprometer al pueblo y al Gobierno en esta política atrevida, empezó por proponer la adopción de una escarapela nacional", el 10 de febrero $1812 .{ }^{4}$

El acontecimiento es relevante porque en él se apoyaba Mitre para despejar cualquier duda sobre el sentimiento que guiaba a los revolucionarios: el plan independentista estaba en marcha y Belgrano era uno de sus principales impulsores. ${ }^{45} \mathrm{Si}$ los documentos hallados "después de estar durante cuarenta años sepultados en el polvo de los archivos" servían a Mitre para probar el acto de creación de la bandera nacional por Belgrano, la narrativa le asignaba el carácter del preludio de una épica, que finalmente se concretaría en las batallas de Tucumán y Salta. La escena de la tarde del 27 de febrero en las barrancas del Paraná, cuando inaugura las baterías Libertad e Independencia, es dotada de la majestuosidad de una pintura patriótica. El vecindario del pequeño pueblo de Rosario reunido y la tropa formada tenían en frente "las floridas islas" y a sus "pies se deslizaban las corrientes del inmenso río, sobre cuya superficies se reflejaban las nubes blancas y azules de un cielo de verano". Una escena nueva, dice Mitre, "calculada para impresionar profundamente los ánimos y comprometer à los tímidos en todas las consecuencias de la revolución". Los allí reunidos y el gobierno que expresó su desagrado lograron ver "el significado que realmente tenía, y vieron en él, algo más que el preliminar de la declaratoria de la independencia". ${ }^{46}$

\footnotetext{
${ }^{43}$ Lugones, Lorenzo (1855) Recuerdos históricos sobre las campañas del ejército auxiliador del Perü en la guerra de la independencia en esclarecimiento de la Memorias póstumas del brigadier general Don José María Paz, Buenos Aires: Imprenta de la Revista.

${ }^{44}$ Mitre, Bartolomé (1859). Historia de Belgrano..., T. I, p. 416.

${ }^{45}$ Contradice el significado que el propio Belgrano le otorga en los documentos que Mitre cita, dejar de ser esclavos y afianzar "las esperanzas de cimentar muy en breve el gran edificio de nuestra libertad civil”, p. 130. Los publica como apéndices del T. I, pp. 599-610.

${ }^{46}$ Mitre, Bartolomé (1859). Historia de Belgrano..., T. I, p. 419.
} 
Al afirmar que se trataba de un sentimiento compartido por todos los revolucionarios, se ponía fin a la duda que había acompañado a Florencio Varela y que Mitre consideraba imprescindible resolver definitivamente. La respuesta es que si no expresaron claramente sus ideas era porque pesaba sobre ellos la sombra de Fernando VII, pero avanzaban resueltamente en el establecimiento de una "verdadera república democrática". ${ }^{47}$ Dicho esto, ese Belgrano que luchaba contra la tiranía, que anteponía el patriotismo a los intereses personales, que reflejaba como ninguno el espíritu de Mayo y las virtudes republicanas y democráticas del pueblo de Buenos Aires, debía ser despojado de la única mella que afectaba su imagen de héroe republicano: su apoyo a la monarquía.

El impulso que dio Belgrano a los proyectos monárquicos fue uno de los asuntos más incómodos para el proceso de construcción de su imagen pública. Ya durante la primera década revolucionaria había sido un motivo de cuestionamientos, ${ }^{48}$ pero fue a partir de la década de 1820 cuando adquirió mayor relevancia al ser utilizado por los opositores de Rivadavia, líder de los unitarios en esa década y un símbolo de esa tradición y del liberalismo porteño en la década de 1850, que se preguntaban si podía cooperar a que la patria se constituyera como una república representativa quien había negociado en 1814 con Carlos IV la coronación de su hijo. ${ }^{49}$ Apenas una página y media alcanzaban para asestar el golpe, el resto del folleto lo ocupaba una carta firmada por Belgrano y Rivadavia que probaba la acusación. Unos años después, desde su exilio en Montevideo, Florencio Varela se hallaba tan preocupado por la ausencia de testimonios que probasen que los revolucionarios de 1810 tenían el plan de independizarse de la corona española, como por la mancha que había dejado la misión de Rivadavia y Belgrano sobre su fe republicana. Con este motivo, publicó "Apuntes para la historia futura de la independencia del Río de la Plata", en el que respondía a la acusación de traidores a la causa de la revolución que se realizaba en un artículo publicado en el Morning Chronicle de Londres y que había reproducido El Heraldo de Madrid. ${ }^{50}$ El argumento de Varela era que el sentido de la misión debía analizarse en un contexto en el que el país pertenecía de derecho a la monarquía española, por lo que no se podía

\footnotetext{
${ }^{47}$ Mitre, Bartolomé (1859). Historia de Belgrano..., T. I, p. 420.

${ }^{48}$ La Crónica Argentina, núm. 17, en Zinny, Antonio (1869) Efemeridografía Argirometropolitana hasta la caída del gobierno de Rosas, Buenos Aires: Imprenta del Plata, pp. 33-37.

${ }^{49} \mathrm{El}$ folleto anónimo impreso en 1825, sin indicación de lugar ni imprenta, se titulaba Reverente súplica al ex-rey Carlos Cuarto, pidiéndole a su hijo adoptivo el infante don Francisco de-Paula, para coronarle en las Provincias del Río de la Plata, por los vasallos del mismo don Manuel Belgrano y don Bernardino Rivadavia.

${ }^{50}$ Varela, Florencio "Apuntes para la historia futura de la independencia del Río de la Plata", en El Heraldo, Madrid, núm. 1717, domingo 9 de enero de 1848, p. 3.
} 
exigir que la misión diplomática tuviera un carácter republicano, que tampoco era una aspiración ampliamente compartida en el Río de la Plata.

Tres cuestiones importantes para nuestro argumento surgen del artículo de Florencio Varela. La primera es que la acusación había permanecido instalada en la memoria colectiva durante más de treinta años. La segunda es que también habían cristalizado los atributos de Belgrano como expresión del patriotismo más desinteresado y más puro, que lo ponía a salvo de las disputas de partido. La tercera es que resultaba evidente que la intención era atacar la imagen de Rivadavia, que había fallecido en 1845, y a través de él a la facción que representaba y de la que Florencio Varela era uno de sus mejores publicistas en el exilio. Pero también, que el ataque publicado en Londres y Madrid pretendía dejar a Belgrano a salvo, fue Varela quien lo reinstaló en ese escenario, para usar su memoria en defensa de la de Rivadavia: "El odio de partido llego al punto, que, en una edición, que no hemos visto, de ese documento, se puso únicamente la firma de D. B. Rivadavia, suprimiendo la del general Belgrano, de cuyo puño y letra poseemos copiada la petición".

La polémica se reactivó con motivo de los homenajes dedicados a Rivadavia en 1857, al retornar sus restos como "Padre de la patria" de una Buenos Aires separada de la Confederación y con fuertes divisiones internas, que el enemigo común apenas lograba disimular. En esa ocasión, La Reforma Pacífica de Carlos Calvo, que se hallaba entre quienes rechazaban esa tradición reivindicada por el oficialismo, denunciaba la operación política que ocultaba ese acto de "los llamados unitarios". Una impostura de quienes "Falsifican la historia con una impudencia que pasma", para servir a los fines de erigirse como los nuevos libertadores y legitimar de ese modo su predominio político en el Estado de Buenos Aires. ${ }^{51}$

En ese contexto, Mitre buscó reivindicar el republicanismo de Belgrano sin negar su inclinación monárquica, que los documentos tornaban inobjetable. Para ello, distinguió dos momentos: el carlotista y el incaico. Mientras el primero era justificado por sus fines, en la medida de que su plan "tenía por base la independencia y la libertad" ${ }^{52}$ el segundo momento, el plan de instaurar una monarquía incaica en 1816, era presentado como signo de la incomprensión, compartida con San Martín, de la opinión predominante en ese momento en los pueblos respecto a la forma de gobierno.

No reiteraba el argumento de Florencio Varela, que ponía en duda el consenso republicano, sino que explicaba su monarquismo por la influencia que ejerció sobre ambos el cambio que se había dado en la opinión europea, que

${ }^{51}$ La Reforma Pacífica, 28 de mayo de 1857. En Halperin Donghi, Tulio (2007) Proyecto y construcción de una Nación, Documentos, Buenos Aires: Emecé, pp. 170-174.

${ }^{52}$ Mitre, Bartolomé (1859). Historia de Belgrano..., T. I, pp. 167-168. 
había mudado de la tentación por "republicanizarlo todo" a la de "monarquizarlo todo", según declaró Belgrano en su discurso al Congreso del 6 de julio de 1816. De este modo, el problema de sus recomendaciones al Congreso no se encontraba en el análisis de las circunstancias que afectaron a quienes a esta altura eran los dos héroes indiscutibles de un panteón todavía inestable, sino en lo inadecuado para el medio en el que debían aplicarse las soluciones que propusieron. A pesar de ello, siempre habían subordinado sus acciones a un bien superior y nunca pusieron sus armas al servicio del plan monárquico. ${ }^{53}$ Cerraba así, o pretendía hacerlo, los grandes interrogantes que se mantenían abiertos acerca de la Revolución de Mayo: ¿había tenido líderes, orientadores y guías?, y si era así, ¿habían tenido ellos un plan de independencia? ¿Ese plan, en caso que lo hubiese, era republicano o se satisfacía con un cambio de monarca o de dinastía? Mitre confiaba en que finalmente su libro pondría fin a las dudas que habían albergado sus contemporáneos sobre la Revolución y sus héroes. ${ }^{54}$ La conclusión era entonces que aun cuando hubieran sostenido en ese momento ideas monárquicas, el curso de la historia los llevó a crear repúblicas y, en cualquier caso, aquellas ideas que no influyeron en el curso "natural" de la historia, hoy ya nadie las recuerda y "se han convertido en polvo". ${ }^{55}$

El último párrafo de la Historia deBelgrano dejaba a San Martín dispuesto a "continuar con más grandeza y con más acierto la tarea encomendada antes a Belgrano" y a este comprometido en la tarea más ingrata de someter el desorden interior. Esa tercera fase de su historia, la de "la revolución social", quedó inconclusa en el proyecto del libro y fue recuperada recién en 1877, cuando escribió la tercera edición con el título de Historia de Belgrano y de la independencia argentina. Sin embargo, la edición de 1859 incluía un "Corolario" a cargo de Domingo Faustino Sarmiento, que al sintetizar el proceso que iba de la declaración de la independencia a la disolución del gobierno nacional y la muerte del héroe de la historia, en 1820, terminaba de atar los cabos sueltos que permitían filiar a Belgrano con el presente y con su historiador. Ambos protagonistas de un proceso que comenzaba en la colonia, se proyectaba con la

\footnotetext{
53 Mitre, Bartolomé (1859). Historia de Belgrano..., T. I, p. 12.

54 “D. Florencio Varela, que se reputa (y con razón) como uno de los que mejor preparados estaban para escribir la historia, decía en 1841 lo siguiente: 'A medida que avanzo en el estudio de los monumentos de nuestra revolución, se hace más espeso el circulo de dudas que me ciñe [...] ¿Creerá Vd. que la más grave y la más oscura de esas dudas es acerca de las verdaderas intenciones de la primera Junta revolucionaria?'”, p. 20. “...Y murió talvez dudando del pensamiento de Mayo!", pp. 32-33. Pero después de la Historia de Belgrano, “...creemos que nadie pondrá a duda ya, si nuestros padres pensaron ò no en constituir una patria libre é independiente en $1810^{\prime \prime}$, p. 34 .

${ }^{55}$ Mitre, Bartolomé (1859). Historia de Belgrano..., T. I, pp. 402-403.
} 
Revolución y la guerra civil y se realizaba en la década de 1850 en su forma republicana y liberal bajo el liderazgo de Bartolomé Mitre. ${ }^{56}$

En 1866, cuando las relaciones con Mitre eran menos amistosas, Sarmiento le recordaba en ese tono de quejoso reproche tan común en su correspondencia que no merecía el desprecio que había sentido en los últimos años, después de que en aquel "Corolario", "cuando usted abandonaba la pluma por la espada, yo ponía su programa y su candidatura en la última página de Belgrano". ${ }^{57}$ Ese acto justificaría en los años siguientes a los críticos que acusaban a Mitre de utilizar a Belgrano con el objetivo de construirse para sí una genealogía heroica y patriótica, sino por la sangre al menos por la pluma.

En esos términos, José Hernández atacaba en 1869 al "émulo de Belgrano", que había involucrado al país en una guerra que provocó la disolución nacional; ${ }^{58}$ y lo mismo haría Juan Bautista Alberdi, que en su autobiografía recordaba que había estudiado en la escuela que fundó Belgrano en Tucumán y que en su niñez había recibido sus caricias. ${ }^{59}$ Pero había algo más profundo en esa discusión, que afectaba a la figura de los héroes elegidos para ocupar un lugar de privilegio en el panteón nacional.

Dejando de lado a Alberdi, cuya crítica se publicó póstumamente y su repercusión es posterior al periodo bajo estudio, fue Dalmacio Vélez Sársfield quien realizó la crítica más demoledora a Manuel Belgrano hasta entonces que, por otro lado, se ventilaba en la prensa y se sometía al juicio de la opinión pública. En la polémica que inició en la prensa en 1864, acusó a Mitre de escribir una historia que con el objetivo de elevar a Belgrano había calumniado la acción de los pueblos. A su juicio, Belgrano tenía un estilo despótico y antidemocrático que lo hacía el menos apto guiar a pueblos que fueron quienes arrastraron a sus líderes a cumplir con sus propios objetivos. ${ }^{60}$

\footnotetext{
56 Domingo F. Sarmiento, "Corolario", en Mitre, Bartolomé (1859). Historia de Belgrano..., T. II, pp. 519-546.

${ }^{57}$ Domingo Faustino Sarmiento a Bartolomé Mitre, Lago Oscawana, New York, 28 de junio de 1866, en Sarmiento-Mitre. Correspondencia 1846-1848, Buenos Aires: Coni Hnos., 1911, pp. 213217.

${ }^{58}$ Hernández, José “Los enemigos del progreso", El Río de la Plata, 15-10-1869, en Halperin Donghi, Tulio (2007) Proyecto y construcción de una nación, 1846-1880, T. II, Documentos, Buenos Aires: Emecé, p. 291.

${ }^{59}$ En "Mi vida privada. Que se pasa toda en la República Argentina", Alberdi, Juan Bautista (1920) Obras Selectas, Tomo IV, Biografías y autobiografías, Buenos Aires: Librería La Facultad, p. 447. En "Belgrano y sus historiadores" lo acusaba de pretender pasar como un segundo Belgrano, "Parece querer hacer la historia de Belgrano después de haberla escrito", en Escritos póstumos, T. V., Buenos Aires: Imprenta Alberto Monkes, 1897, p. 7.

${ }^{60}$ Vélez Sársfield, Dalmacio "Rectificaciones históricas por el doctor Dalmacio Vélez Sársfield", en Mitre, Bartolomé (1864) Estudios históricos sobre la revolución argentina, Buenos Aires: Imprenta del Comercio del Plata, pp. 215 y ss.
} 
De todos modos, escaso impacto sobre la imagen de Belgrano tuvieron las críticas de Vélez Sarsfield. Uno de los motivos, puede hallarse una vez más en el "Corolario" escrito por Sarmiento. ¿Quién era el Belgrano de Sarmiento, el que el lector Sarmiento leyó en la Historia de Belgrano?: “...una figura histórica que no brilló por sus apariencias, ni brilló por el genio de la guerra, como San Martín, ni dejó rastros imperecederos en instituciones fundamentales como Rivadavia". Es quien aparece en la escena política sin ostentación, sin que lo echen de menos y muere olvidado, oscurecido y miserable. Es decir, un héroe mucho menos brillante que el que elaboró Mitre en las primeras dos versiones de su biografía, al que le niega otras victorias para sobresaltar sus derrotas. Más cercano, en cambio, al enigma que retrata Tulio Halperin Donghi, el que de acuerdo a sus escasos méritos en términos de genio, fortuna y capacidades habilita la pregunta acerca de por qué ocupó ese lugar de privilegio en el panteón de héroes nacionales.

Pero a diferencia del autor de El enigma Belgrano, Sarmiento no cree que la respuesta se encuentre en su biografía familiar sino en que era el héroe que correspondía a ese momento de Buenos Aires. Se trataba de un simple y buen ciudadano, que vivió una época homologable a la actual, que necesitaba un espejo en que mirarse y lo encontró en quien "Poco ha hecho que cada uno no se crea capaz de hacer...", pero que tenía un conjunto de virtudes, que no eran otras que aquellas que la poesía patriótica destacó desde el año 1820 y que Sarmiento juzgaba menos excepcionales que imprescindibles: patriotismo puro, abnegación en la desgracia, perseverancia en el propósito, lealtad a los buenos principios: "la noble figura de Belgrano comienza a sacudirse el polvo de olvido que la cubría, y a mostrase espléndida de las dotes y virtudes que pide el pueblo, a fin de ver reflejadas en los objetos de su culto sus propias aspiraciones". ${ }^{61}$ Probablemente ese es el motivo por el que las críticas a Belgrano no estuvieron ausentes pero fueron perdiendo peso en el culto a la tradición de Mayo, que encontraba en Belgrano "la moral de nuestra historia", uno de los pocos que no necesitaban pedir perdón a la "posteridad y a la severa crítica histórica" .

La historia dejaba paso a la memoria. Desde la década de 1850 se iba a construir una galería de héroes en la que Belgrano, junto a San Martín y Rivadavia, ocuparía un lugar central. En su caso, probablemente estimulado por el protagonismo que adquiría en las Memorias de Paz y por las intervenciones que motivó por parte de La Madrid y Lugones, a partir de 1855 una serie de dispositivos visuales y gráficos contribuyeron a la multiplicación de su imagen. La lápida deslucida en la que ya casi no podía leerse su nombre fue reemplazada ese año; se fundó finalmente el pueblo de Belgrano, que había

${ }^{61}$ Sarmiento, Domingo Faustino “Corolario", p. 532. 
sido proyectado en 1821; en 1858 se levantó un primer monumento en Luján, un busto en barro cocido sobre una columna dórica de 14 metros; y en 1857 se publicaba la Galería de Celebridades argentinas, ${ }^{62}$ en la que Mitre ofreció la Biografía de Belgrano, el mismo año del retorno de los restos de Rivadavia como "padre de la patria" y del juicio a Juan Manuel de Rosas, que culminó con su condena como "reo de lesa patria". Todas esas acciones formaron parte de un proyecto republicano que buscó a través de sus héroes filiar a Buenos Aires con la Revolución de Mayo y la gesta de la independencia; y a sus líderes con quienes antes que ellos lucharon a favor de la causa de la libertad, cuando se enfrentaban a un proyecto de unidad nacional que las exponía ante el mundo como una provincia rebelde.

Las celebraciones y homenajes, la posesión y exhibición de las reliquias de los héroes -sus cuerpos y su atributos, como la bandera del Ejército de los Andes, que en 1859 fue depositada en manos del gobernador de Buenos Aires en un acto solemne- ${ }^{63}$ eran el modo de sellar simbólicamente esa filiación y poner en línea el presente con el pasado glorioso y ambos con la posteridad. La Galería de celebridades argentinas correspondía a esa ética conmemorativa, se trataba de un monumento republicano a sus héroes (Amigo, 1999: 11-56; Wasserman, 2008: 69-74).

En el caso de Belgrano, su figura se destacaba entre los héroes porteños y su fisonomía comenzaba a definirse a través de la biografía que escribió Bartolomé Mitre y del dibujo realizado por Narcisse Desmadryl, sobre la base del retrato que realizó Carbonnier en 1815. Reproducida a través de las litografías del taller de Jules Pelvilain, puso en circulación la imagen de un Belgrano ciudadano, enmarcado en un cuadro oval que perduraría por varias generaciones. ${ }^{64}$ Sin embargo, en los años siguientes esa imagen rotaría hacia la del general asociado al acto de creación de la bandera. En 1862, cuando Mitre había asumido la presidencia, Prilidiano Pueyrredon realizó un boceto del juramento de la bandera destinado a la casa de gobierno que presidía su biógrafo. Aun cuando quedó inconcluso, es un testimonio del temprano éxito que halló el encuentro de la bandera con quien Mitre había descubierto como su

\footnotetext{
${ }^{62}$ Galería de celebridades argentinas biografía de los personajes más notables del Río de la Plata, Buenos Aires: Ledoux y Vignal editores, 1857.

${ }^{63}$ El acto fue celebrado el 28 de febrero de 1859. Cfr. Martínez, Enrique (1873) Reseña de las glorias adquiridas por el Ejército de los Andes con la bandera que deposité en manos de S.E. Sr. Gobernador del Estado, Doctor Don Valentín Alsina, Buenos Aires: Imprenta El nacional.

${ }^{64}$ Además de la biografía de Belgrano, se publicaron las San Martín, Moreno, Brown, Rivadavia, Funes, García, Florencio Varela y Lavalle.
} 
creador. Era la imagen de la nación en armas en defensa de la libertad recién conquistada bajo el liderazgo de Buenos Aires. ${ }^{65}$

Ese mismo año, la ciudad de Rosario celebraba por primera vez el fugaz episodio en el que Belgrano enarboló la bandera en sus barrancas, el 27 de febrero de 1812. De ese modo, buscaba dotar su crecimiento de una más ilustre memoria histórica al asociarse con el acto que daba origen a la nación argentina. Desde 1862, una serie de iniciativas buscaron ese reconocimiento en un relato que sería complementado y reconvertido en tradición con el recuerdo de Cosme Maciel, el vecino de la entonces aldea que habría izado la bandera por primera vez. ${ }^{66}$ Es probable que la tradición oral fuese una consecuencia de esa primera celebración y no su antecedente, lo cierto es que a partir de ese momento sería la fuente principal junto a la Historia escrita por Mitre para confrontar contra cualquier intento de poner en discusión el privilegio de Rosario como lugar en el que se creó el "principal símbolo nacional". Ese mismo año Eudoro Carrasco impulsó la confección de un escudo que oficiaba como auto-representación de la ciudad: el progreso representado por las alegorías relativas a su carácter de puerto agrícola junto a los atributos que Mitre le acababa de conferir como sitio de la creación de la bandera nacional. ${ }^{67}$

Durante años, Rosario intentó que ese lugar que pretendía fuese reconocido en toda la nación y los distintos monumentos proyectados fueron uno de los dispositivos a través de los cuales quiso materializar ese reconocimiento (Couselo, 2011; 2015). En 1872, Grondona se apoyaba en el relato de la Historia de Belgrano y en los documentos incorporados en el apéndice del Tomo II, para proponer que se levantara un monumento conmemorativo en el que la creación de la bandera quedaba asociada como hito fundacional de la nación, con un estatus similar al de la Revolución de Mayo en 1810 y a la Declaración de la independencia, el 9 de julio de $1816 .{ }^{68}$

En ese momento, la imagen de Belgrano como héroe nacional y creador de la bandera había cristalizado en la tradición nacional. Billetes y estampillas hacían circular su rostro entre la población. Su imagen, basada en la pintura que

\footnotetext{
${ }_{65}$ Pueyrredon, Prilidiano Juramento de la Bandera por el ejército de Belgrano el 13 de febrero de 1813, 1862. Acuarela s/cartón, 44,5 X65 cm. Colección Complejo Museográfico Provincial “Enrique Udaondo".

${ }^{66}$ Obligado, Pastor (1900) "El que hizo la primera bandera", en Tradiciones de Buenos Aires 15801880, 5ta serie, Buenos Aires: Establecimiento tipográfico "Galileo", pp. 19-25.

${ }^{67}$ La filiación del símbolo con su fuente fue reconocida formalmente en 1894 por Gabriel Carrasco, cuando en la dedicatoria a Mitre confirmaba que su padre había tomado la idea "...de la revelación histórica hecha por Vd. en La Historia de Belgrano, relativa a la invención de la bandera nacional". Allí se hallaba la clave de una historia que "conmemora un hecho grandioso y único, no tan solo en la historia de Rosario, sino también en la de toda la República". Carrasco, Eudoro y Gabriel (1897). Anales de la ciudad de Rosario, Rosario: Peuser, pp. 545-549. ${ }_{68}$ Monumento conmemorativo a la bandera nacional, Rosario, Imprenta Monzón, 1872, pp. 21-28.
} 
realizó Carbonnier en 1815, aparecía por primera vez en el billete de 200 pesos fuertes de 1869, que emitió el Banco de la Provincia de Buenos Aires. Junto a San Martín, será a partir de allí el más retratado en la numismática argentina.

Finalmente, el ciclo de construcción de la figura pública de Belgrano se cierra el 24 de septiembre de 1873, cuando a 61 años de la batalla de Tucumán se inauguraba en la Plaza de Mayo de Buenos Aires la estatua ecuestre de Belgrano $^{69}$ realizada en París por Albert Ernest Carrier-Belleuse y Manuel de Santa Coloma. En ella Belgrano era representado con sus atributos militares "mirando con una indecible expresión de cariño el pabellón de la patria, que ostenta en su mano derecha". ${ }^{70}$ Los discursos que pronunciaron Bartolomé Mitre, el ex presidente, biógrafo de Belgrano y miembro de la comisión a cuyo cargo estuvo la obra; ${ }^{71}$ y Domingo F. Sarmiento, en su condición de Presidente de la Nación, desplazaron el aporte de Belgrano al éxito de la independencia para privilegiar sus valores morales y la creación de la bandera nacional. Una vez más, del contraste con los "genios" de la Revolución surgió su singularidad. No se trataba de "un general con el genio de San Martín, ni un economista del alcance de Vieytes, ni tribuno con la elocuencia de Castelli, ni un jurisconsulto de la ciencia de Castro, ni un escritor con el temple de Monteagudo, ni un pensador de la profundidad de Moreno ni un político de la talla de Rivadavia". Fue un poco todo eso, decía Mitre en su discurso, un modesto actor en una época memorable, que no pretendió ir más allá de la razón pública.

$\mathrm{Su}$ gloria pura y modesta era la que mejor se asociaba a la humildad de un pueblo republicano: "Es el tipo ideal del héroe modesto de las democracias" al que se le reconoce con una estatua realizada por contribución pública, "como corresponde a los grandes hombres de una nación libre", decía Mitre. Por su parte, Sarmiento recuperaba como sus principales virtudes la resignación y la esperanza, la honradez y el trabajo desinteresado. Ideal para un país que no había anexado los territorios que había contribuido a independizar, y que ahora recibía a todos los hombres del mundo que bajo esa bandera encontraban su lugar. ${ }^{72}$

Es Sarmiento el que termina de dar sentido a su representación monumental, "el general porta-estandarte". Con el reconocimiento de ese acto, que en 1859 era apenas un episodio de la gesta del héroe, como la mayor

\footnotetext{
${ }^{69}$ La estatua había sido proyectada en 1860 junto a la de San Martín, que se inauguró en 1863 (Munilla Lacasa, 1999: 152).

${ }^{70}$ El Americano, núm. 44, París, 27 de enero de 1873.

${ }^{71}$ Mitre, Bartolomé (1902) "En la inauguración de la Estatua de Belgrano", en Arengas, T. II, Buenos Aires: La Nación, pp. 188-190.

${ }^{72}$ Discurso pronunciado por el presidente de la República D. Domingo F. Sarmiento en honor de la Bandera Nacional al inaugurarse la estatua del general Belgrano, 24 de setiembre de 1873, Buenos Aires: Imprenta de la tribuna.
} 
contribución de Belgrano se volvían a encontrar el autor de la Historia de Belgrano y el del "Corolario". Respecto de aquella versión no había diferencias interpretativas, sino la que resultaba de los diversos contextos. En 1873, se trataba de una conmemoración de la nación y no ya de una provincia que había rechazado la Constitución nacional de 1853 y que en 1859 se encontraba al borde de un nuevo enfrentamiento armado contra la Confederación Argentina liderada por Urquiza. Era un homenaje a Belgrano, a la bandera como símbolo del origen de la nación y a las glorias de las guerras de independencia homenajeadas por medio de la bandera del Ejército de los Andes, la misma que el General Enrique Martínez había entregado al Gobernador de Buenos Aires en 1859, custodiada por una Guardia de Honor formada por generales, jefes, soldados e inválidos de los Ejércitos de la Independencia. ${ }^{73}$

El ciclo había concluido, devuelto de la historia a la memoria y la tradición, el mejor de los hijos de Buenos Aires que falleció en 1820 cuando su pueblo más lo necesitaba, devenía en expresión de las virtudes que correspondían a un pueblo republicano: las del buen ciudadano, que obediente y desinteresado anteponía la razón pública a sus propias ideas y deseos. Cuatro años después se publicaba la versión definitiva de la Historia de Belgrano y de la independencia argentina. Se le agregaba un capítulo introductorio, el de la sociabilidad en el Río de la Plata, y los capítulos que cubrían el periodo que había quedado inconcluso en 1859, desde la declaración de la independencia y el comienzo de la revolución social hasta la disolución del gobierno nacional en 1820 y el fallecimiento del héroe. En esos capítulos incorporados en 1877, las virtudes de Belgrano adquirían un carácter social, eran la expresión más acabada de una conciencia nacional colectiva cuyas rasgos republicanos y democráticos se hallaban en germen desde el comienzo del proceso de colonización y poblamiento del Río de la Plata.

\section{Reflexiones finales}

El punto de partida de este artículo fue el "enigma" Belgrano, tal como lo formuló Tulio Halperin Donghi en su último libro. He intentado mostrar que la pregunta acerca de por qué otorgar un lugar de privilegio a quien había deambulado entre éxitos y fracasos a lo largo de diez años, ya había sido de algún modo planteada y resuelta a lo largo de los cincuenta años posteriores a su muerte.

A diferencia del camino elegido por Tulio Halperin Donghi, he buscado responder a esa pregunta no a través de su biografía sino a lo largo del proceso

${ }^{73}$ Decreto 9683, “Inauguración de la estatua ecuestre del general D. Manuel Belgrano, Registro Nacional de la República Argentina, T. VI, Buenos Aires: La República, pp. 470 y 771 
de construcción de su figura ejemplar. Beatriz Bragoni señaló que San Martín tuvo la posibilidad de modelar su propia biografía para la posteridad (Bragoni, 2019). Con Belgrano no sucedió lo mismo. Murió cuando el futuro de las nuevas provincias era todavía incierto y apenas dejó una breve autobiografía, algunos escritos, cartas y comunicaciones oficiales, que sirvieron de fuentes para la construcción de su imagen junto a los recuerdos transmitidos oralmente por quienes lo conocieron. De todos modos, la coincidencia de su muerte con la crisis que puso fin a la etapa gloriosa de la Revolución, que a partir de allí solo podía ser recordada con nostalgia, fue central para filiar su caída a la de Buenos Aires y su memoria a la salvación de la ex metrópoli virreinal que lo había reconocido como el mejor de sus hijos.

A través del análisis de los homenajes y evocaciones intenté mostrar que no es el enigma su caracter de héroe, por el contrario es el tipo de héroe cuya caída es la condición de su ascenso. A partir de allí, reconstruimos los diversos modos y momentos de plasmación de su imagen pública elaborada a partir del consenso respecto de los atributos que lo convertían en un ciudadano cuya ejemplaridad radicaba en que se trataba de un hombre común.

En todo caso, hay otros dos enigmas en torno a su figura que merecían alguna exploración. En primer lugar, la pregunta acerca de cómo se convirtió en héroe nacional una figura que fue siempre reconocido como un hombre fiel al gobierno de Buenos Aires, que los pueblos miraban con desconfianza y que hasta el final comprometió su ejército en la defensa del directorio y la constitución centralista de 1819. Su carácter de héroe de la nación se fue perfilando en la década de 1850, y se consolidó con el liderazgo político de Buenos Aires a nivel nacional a partir de 1861. Finalmente, la inauguración del monumento en 1873 fue un momento de condensación de discursos, símbolos, imágenes y figuraciones ya asentadas pero que ahora eran plasmadas por el Estado Nacional.

El segundo enigma es por qué elegir como héroe de una república federal y democrática, en la Buenos Aires que se ofrecía como modelo al resto de las provincias, a un personaje que había defendido principios monárquicos y centralistas. A lo largo de cincuenta años la filiación de Belgrano a ideas contrarias al curso de la historia nacional saldría a la luz una y otra vez. La fórmula que encontró Mitre fue eficaz, tanto en su caso como en el de San Martín. No se trataba de negar lo que los documentos que él mismo se encargaba de publicitar exhibían a la opinión pública, ni de justificar por el contexto como lo había hecho Florencio Varela. Se trataba en cambio de destacar que sus ideas finalmente no habían cambiado el destino del país y eso era así porque no estuvo dispuesto a usar su espada para defenderlas. 
En las décadas siguientes, el sitial que le correspondía a Belgrano y San Martín se fue sedimentando tanto en lo que refiere a la forma como al contenido. Cuánto contribuyó a ello la historia escrita por Mitre es difícil afirmarlo, aunque sin duda sirvió para actualizar y estilizar los argumentos que se utilizaron en la elaboración de su imagen pública desde 1820. Si alguna prueba hay del éxito de esa construcción colectiva, se encuentra en el dato de que a partir de la segunda mitad del siglo XIX no sufrió intentos de apropiación por partidos, provincias o grupos políticos que intentaran fundar su identidad en torno a su nombre. Por el contrario, el líder de una de las últimas montoneras contra el gobierno nacional liderado por Bartolomé Mitre ofrecía en 1867 el testimonio de que solo podía ser evocado en nombre de la nación y no en favor de una fracción de ella, utilizando para ello la figura elaborada por su opositor: “¡argentinos todos! ¡Llegó el día de mejor porvenir para la patria! a vosotros cumple ahora levantar del noble suelo ensangrentado el pabellón de Belgrano, para enarbolarlo gloriosamente sobre las cabezas de nuestro liberticidas enemigos" ${ }^{74}$

Rosario, abril 2020

\section{Bibliografía citada}

Amigo, Roberto (1999). "Imágenes de la historia y discurso político en el Estado de Buenos Aires (1852-1862)", en Amigo, Roberto y Doso, Patricia Arte Argentino de los Siglos XVIII y/o XIX, Buenos Aires: FIAAR, pp. 11-56.

Barcia, Pedro (2001). "La inédita Colección de Poesías Patrióticas", en Boletín de la Academia Argentina de Letras, LXVI, pp. 109-145.

Barcia, Pedro Luis (1982). "Estudio preliminar", en La Lira Argentina o Colección de las piezas poéticas, dadas a luz en Buenos Aires durante la guerra de su Independencia, Buenos Aires: Academia Argentina de Letras, [disponible en línea: dehttp://www.cervantesvirtual.com/obra-visor/la-lira-argentina-ocoleccion-de-las-piezas-poeticas-dadas-a-luz-en-buenos-aires-durante-laguerra-de-su-independencia--0/html/].

Bragoni, Beatriz (2019) San Martín, Una biografía política del libertador, Buenos Aires: Edhasa.

Campbell, Joseph (1972). El héroe de las mil caras. Psicoanálisis del mito, México: FCE.

Cattaruzza, Alejandro y Eujanian, Alejandro (2003). Políticas de la historia. Argentina, 1860-1960, Buenos Aires: Alianza.

\footnotetext{
${ }^{74}$ Coronel Felipe Varela, “Proclama”, en Halperin Donghi, Tulio (2007) Proyecto y construcción..., pp. 256-257.
} 
Couselo, Gabriela (2011). "La celebración del pasado en la ciudad: un Monumento a la Bandera para Rosario", en Revista Electrónica de Fuentes y Archivos, Centro de Estudios Históricos "Prof. Carlos S. A. Segreti", Córdoba, Año 2, núm. 2, pp. 90-112.

Couselo, Gabriela (2015). "Una obra de ineptos oficiales marmoleros. Preguntas y reflexiones en torno al monumento a la bandera de Lola Mora para la ciudad de Rosario, un recorrido desde el Centenario hasta la década del '90”, en Eujanian, Alejandro, Pasolini, Ricardo y Spinelli, María Estella (comps.) Episodios de la cultura histórica argentina. Celebraciones, imágenes y representaciones del pasado (Siglos XIX y XX), Buenos Aires: Biblos, pp. 67-84.

Eujanian, Alejandro y Ternavasio, Marcela (2016). (comps.) Halperin Donghi y sus mundos, Rosario: FHUMYAR ediciones.

Eujanian, Alejandro (2018). “Tulio Halperin Donghi, la generación 'denuncialista' y la relectura de un inventario", en Boletín del Instituto de Historia Argentina y Americana "Dr. Emilio Ravignani", Tercera Serie, Número Especial, pp. 75-85.

Eujanian, Alejandro (2015). El pasado en el péndulo de la política. Rosas, la provincia y la nación en el debate político de Buenos Aires, 1852-1861, Bernal: Universidad Nacional de Quilmes.

Di Meglio, Gabriel (2014). Manuel Dorrego: Vida y muerte de un líder popular, Buenos Aires: Edhasa.

Halperin Donghi, Tulio (2014). El enigma Belgrano. Un héroe para nuestro tiempo, Buenos Aires: Siglo XXI.

Halperin Donghi, Tulio (2013). Letrados y pensadores. El perfilamento del intelectual hispanoamericano en el siglo XIX, Buenos Aires: Emecé.

Munilla Lacasa, María Lía (2010). Celebrar y gobernar: un estudio de las fiestas cívicas en Buenos Aires, 1810-1835, Tesis doctoral, Buenos Aires: Universidad Torcuato Di Tella.

Munilla Lacasa, María Lía (1999). “Siglo XIX: 1810-1870”, en Burucúa, José Emilio Nueva historia argentina: arte, sociedad y política, Buenos Aires: Sudamericana, pp. 105-160.

Myers, Jorge (2004). “Identidades porteñas. El discurso ilustrado en torno a la nación y el rol de la prensa: El Argos de Buenos Aires, 1821-1825", en Alonso, Paula (comp.) Construcciones impresas: Panfletos, diarios y revistas en la formación de los estados nacionales en América Latina 1820-1920, Buenos Aires: FCE, pp. 3963.

Wasserman, Fabio (2008). Entre Clío y la polis. Conocimiento del histórico y representaciones del pasado en el Río de la Plata (1830-1860), Buenos Aires: Teseo. 